\title{
Predicting the Capacity of Receiving Wastewater of Thuong River in Vietnam and Propose Policies for Water Resources Protection
}

\author{
Trinh Thi Thu Van ${ }^{1, *}$, Bui Cong Quang ${ }^{2}$, Nguyen Duc Viet ${ }^{3}$, Nguyen Tung Phong ${ }^{4}$ \\ ${ }^{1}$ Department of Water Resources Management, Ministry of Natural Resources and Environment, Hanoi, Vietnam \\ ${ }^{2}$ Faculty of Hydrology and Water Resources, Thuyloi University, Hanoi, Vietnam \\ ${ }^{3}$ Directorate of Water Resources, Ministry of Agriculture and Rural Development, Hanoi, Vietnam \\ ${ }^{4}$ Vietnam Academy for Water Resources, Ministry of Agriculture and Rural Development, Hanoi, Vietnam \\ Email address: \\ trinhthuvan46v@gmail.com (T. T. T. Van), quangdht148@gmail.com (B. C. Quang), vietnd@wrd.gov.vn (N. D. Viet), \\ phongicd@gmail.com (N. T. Phong) \\ ${ }^{*}$ Corresponding author
}

\section{To cite this article:}

Trinh Thi Thu Van, Bui Cong Quang, Nguyen Duc Viet, Nguyen Tung Phong. Predicting the Capacity of Receiving Wastewater of Thuong River in Vietnam and Propose Policies for Water Resources Protection. International Journal of Environmental Monitoring and Analysis. Vol. 6, No. 1, 2018, pp. 1-12. doi: 10.11648/j.ijema.20180601.11

Received: January 19, 2018; Accepted: January 31, 2018; Published: March 5, 2018

\begin{abstract}
Thuong river - a tributary of the Red River in Vietnam, is currently facing the degradation in both water quality and quantity. One of the major causes of water pollution is wastewater discharge into the river from industrial plants, agricultural and residential areas where wastewater is untreated or treated but does not meet the Vietnamese standards. This report presents the results of predicting the capacity of receiving wastewater of Thuong river from the Cau Son hydrological station to Pha Lai hydrological station in 2020 and 2030 with 3 scenarios: (i) The amount of waste water increases according to plan, but not treated, (ii) $30 \%$ waste water is treated, (iii) $70 \%$ waste water is treated. The method is the application of the MIKE 11 model combined with the waste load calculation formula. The results showed that, in many river stretches, especially the stretches run through Bac Giang city and industrial areas, the river pollution is increasingly serious, and has no signs of stop. Therefore, it is necessary to propose the water policies to control the wastewater discharge into the Thuong River in particular and the Red River system in general in order to protect water resource.
\end{abstract}

Keywords: Receiving Wastewater, Water Quality, Model MIKE 11, Water Policy, Thuong River

\section{Introduction}

The Law on Water resources 2012 [1] of Vietnam regulates some new provisions on water resources management and protection, especially the field of wastewater discharge management. The Article 37 of the Law states: "The organizations and individuals who discharge waste water into water sources must have a permit issued by the State competent agencies (excluding the small scale and waste water without a harmful chemical or radiative matter). One of the basis to grant a permit is capacity of receiving wastewater according to the Decree No. 201/2013/ND-CP, 2013 [2].
Capacity of receiving wastewater of river is the loading capacity to receive a number of pollutants while still maintains the concentration of pollutants in the water sources which does not exceed the allowable values specified in the national water quality standards in the Circular 09/2009/TTBTNMT, MONRE Vietnam [3]. The assessment of capacity of receiving wastewater requires not only have a good long term investigation of hydrology, hydraulic and wastewater discharge activities, but also to assess and predict water quality in the future. Therefore, a technical approach should be applied. 
Thuong River (also known as Nhat Duc River) is located in the territory of Lang Son, Bac Giang and Hai Duong province. It originates from the $\mathrm{Na} \mathrm{Pa}$ Phuoc mountain (belonging to Lang Son province), and then flows into Bac Giang province (through Lang Giang, Yen The, Tan Yen, Yen Dung district and Bac Giang City). The last point of the river is at Pha Lai town of Hai Duong province and enters Luc Nam and Cau river to Thai Binh river. It has $157 \mathrm{~km}$ length and basin area of $6,640 \mathrm{~km}^{2}$ [4].

The selected study area is Thuong river located in Bac Giang province (Figure 1). The total population in Bac Giang province is $1,641,231$ people, of whom the urban population is $136.021(18 \%)$ and people living in rural area is 614,312 $(82 \%)$ [4]. The growth rate of gross domestic product (GRDP) in 2015 was estimated 9.6\%. Thuong river has more than 440 works extracting surface water to serve the industrial production, agriculture, fisheries, living, medical and other service activities; and a total of 946 facilities discharge wastewater into river [4].

Topography of this area is mountainous and midland intersperses plain. Climate is tropical monsoon. In winter, the weather is cold, dry and less rainy due to the influence of the Northeast monsoon. The summer is hot, high humidity and rainy. Rainy season lasts from June to October, the dry season is from November to May. The annual average rainfall is only $1,527 \mathrm{~mm}$, the annual flow module is $15-20 \mathrm{l} / \mathrm{s} / \mathrm{km}^{2}$ and total flow is about 1.93 billion $\mathrm{m}^{3}$ [5].

As the plan from 2006 to 2020, many industrial clusters and parks are to be built in Bac Giang province, that lead to increasing water demands and wastewater discharge to the environment. Many studies showed that the nutrients and organic pollution in Thuong river are significant [4]. The results of water quality analysis of Thuong river (2009 - 2013) showed that the concentration of $\mathrm{BOD}_{5}$ was higher than acceptable standard 1,86 - 3,6 times; COD was higher 1,4 - 2,73 times; $\mathrm{NO}_{3}$ was higher 1,175 - 8,03 times and DO was lower 5,3 times in comparison with the standard [6].

It can be seen that, the issue of river water pollution is causing a sensation in the public opinion and poses an urgent task to the environmental and water resources management authorities and scientists. Finding a solution to control and manage wastewater discharge operation into Thuong river to protect this water source is essential.

Nowadays, the mathematical model application in the water quality evaluation is very popular such as application of models: QUAL2E, WASP, AQUATOX, Cormix, Delft 3D Flow, SMS, Mike 11, etc. However, before selecting a model for analysis, reviewing abilities and characteristics of the models must be carried out [7].

After analyzing the data requirements of these models as well as the ability to apply for the research area, we found that Mike 11 model is the most suitable for the study area. Mike 11 model-an unsteady hydraulic model has provides engineers with highly accurate hydraulic and water quality modeling tool, is selected. The primary feature of Mike 11 modeling system is the integrated structure with a variety of add-on modules each simulating phenomenon related to river systems [8]. To solve the problem of this study, apply three following modules: Hydrodynamic (HD), Advection - Dispersion (AD) and Ecolab. The application of Mike 11 model in the assessment of water quality has been well received among a large number of researches [9, 10].

\section{Data Analysis}

The particular case of this topic is calculation for an unsteady one-dimension flow in the natural canal, thus, the data includes:

\subsection{Hydrological and Hydraulic Data}

- Across section: The study area includes 34 across section.

- Water discharge: Is the daily average data in dry season of the upper boundary station (Cau Son station)

- Water level: Is the daily average data in dry season of the lower boundary station (Pha Lai station) and inspectioning boundary station (Phu Lang Thuong station).

The period for model calibration is in dry season, from $1 / 11 / 2003-31 / 5 / 2004$ and for verification is from $1 / 11 / 2012$ $-31 / 5 / 2013$.

\subsection{Water Quality Data}

- The water quality indicators: Dissolved oxygen (DO), Temperature $\left(\mathrm{T}^{\circ}\right)$, Amonia $\left(\mathrm{NH}_{4}^{+}\right)$, Nitrat $\left(\mathrm{NO}_{3}{ }^{-}\right)$, Biological Oxygen Demand $\left(\mathrm{BOD}_{5}\right)$, Phosphorus $\left(\mathrm{PO}_{4}{ }^{3-}\right)$, Total coliform.

- The wastewater sources data:

The data of pollution sources including: The pollutants concentration, wastewater discharge and location of wastewater sources.

- Surface water quality data:

The data of surface water quality including: The pollutants concentration, water discharge and locations at the station boundary and some monitoring points on the river.

- Wastewater discharge prediction data: Based on the water resources planning and the socio-economic planning.

These data are collected from believable sources of MoNRE, Vietnam. The summary of the data used can be found in Table 1, the geographic location of the hydrology stations are presented in Figure 1 and the water quality sampling sites in 2013 and 2016 are shown in Figure 2. 
International Journal of Environmental Monitoring and Analysis 2018; 6(1): 1-12

3

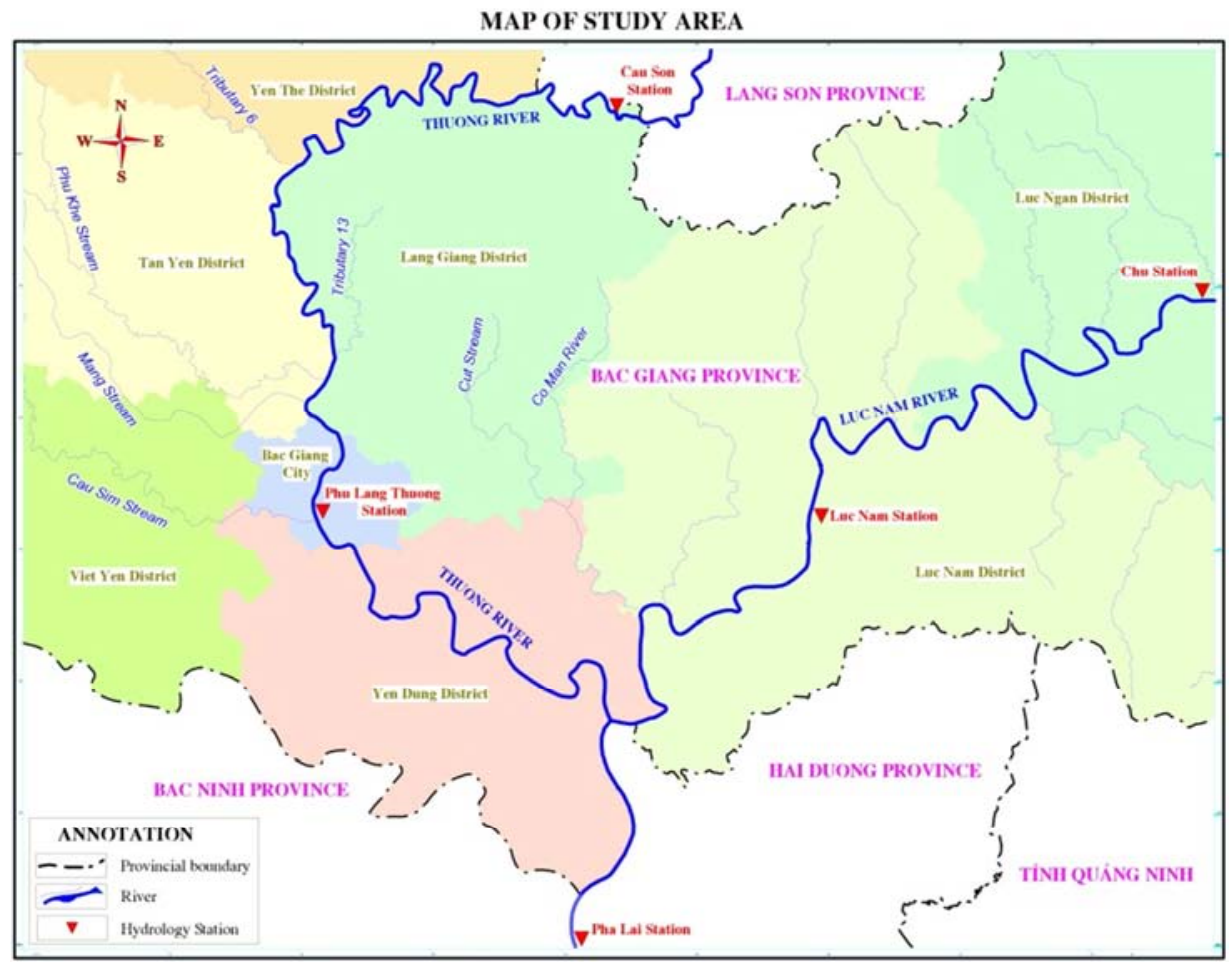

Figure 1. Map of study area - Throng river, Vietnam.
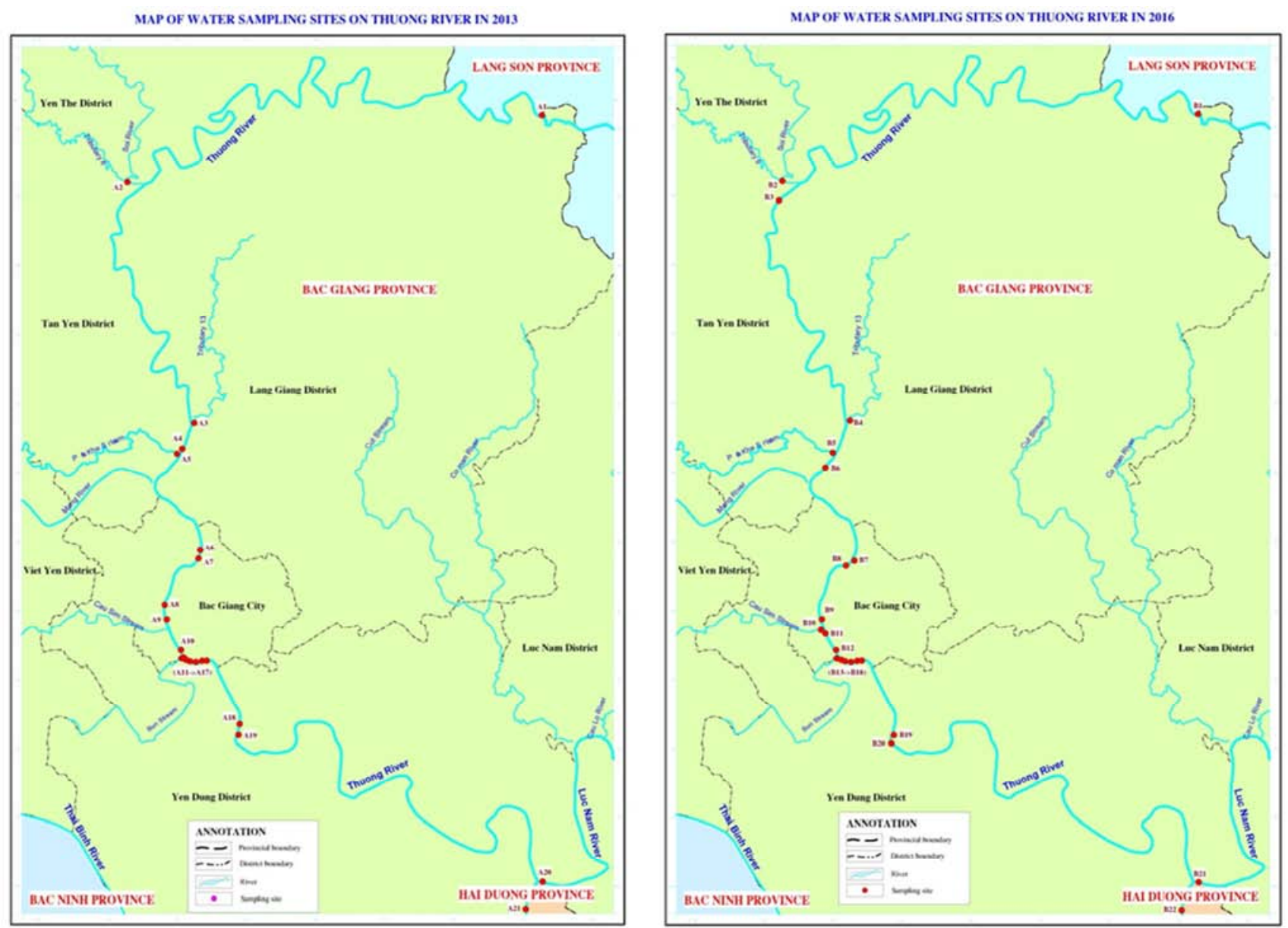

Figure 2. Map of sampling sites in 2013 and 2016. 
Table 1. Summary of the data used in the study.

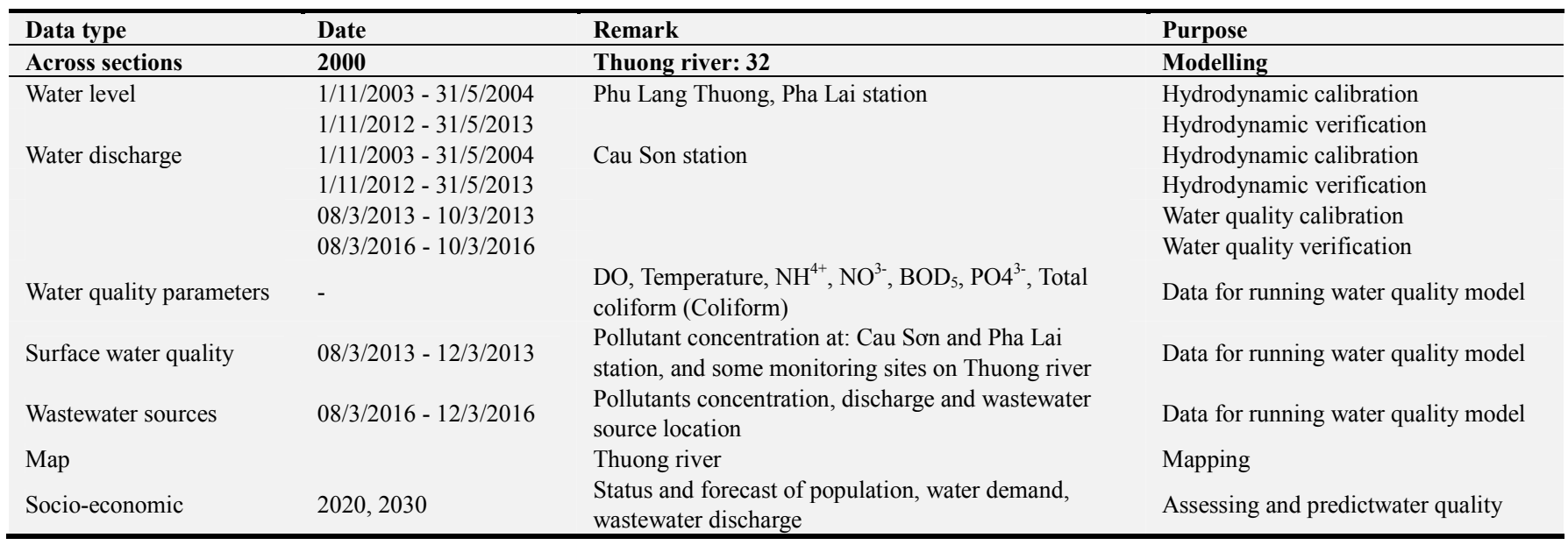

\section{Methodology}

The assessment is undertaken in four different steps.

(i) The first step simulates hydraulic and hydrological status to identify the hydraulic parameters using Hydrodynamic module (HD) of Mike 11 model.

(ii) The second step identifies water quality parameters of Advection - Dispersion module (AD) and Ecobal module including physical parameters and biological parameter as coefficient of diffusion, respiratory, photosynthesis, etc.

(iii) The third step includes assessment of water quality in the future based on scenarios and identifying water quality objectives in each river sections.

(iv) The last step involves assessment of the capacity of receiving wastewater of Thuong river based on the contamination of pollutants along the river (the results of step 3 ) and using some equations to assess capacity of receiving wastewater.

\subsection{Hydrodynamic Module (HD)}

The purpose of hydraulic calculation is to find the hydraulic parameters in order to assess water quality in the study areas. The hydraulic parameter is Manning roughness coefficient.

Hydrodynamic module built from the equations of continuity and momentum (the 'Saint Venant' equations).

The equation of continuity:

$$
\frac{\partial Q}{\partial x}+\frac{\partial A}{\partial t}=q
$$

The equation of momentum:

$$
\frac{\partial Q}{\partial t}=\frac{\partial\left(\alpha \frac{Q^{2}}{A}\right.}{\partial x}+g A \frac{\partial h}{\partial x}+\frac{g Q Q}{C^{2} A R}=0
$$

Where:

- Q: Discharge $\left(\mathrm{m}^{3} / \mathrm{s}\right)$

- A: Flow area $\left(\mathrm{m}^{2}\right)$

- q: Lateral inflow $\left(\mathrm{m}^{2} / \mathrm{s}\right)$
- C: Chezy resistance coefficient $\left(\mathrm{m}^{1 / 2} / \mathrm{s}\right)$

- $\alpha$ : Momentum distribution coefficient.

- R: Hydraulic or resistance radius (m).

\subsection{Advection - Dispersion (AD) and Ecolab Module}

The purpose of running $\mathrm{AD}$ and Ecolab module is to determine the most suitable water quality parameters for the study. Then, using these parameters to predict water quality changes based on the scenarios, thereby assess the capacity of receiving wastewater.

The basic equation of these modules is Advection Dispersion equation:

$$
\frac{\partial A C}{\partial t}+\frac{\partial Q C}{\partial x}-\frac{\partial}{\partial x}\left(A D \frac{\partial C}{\partial x)}\right)=-A K C+C_{2} q
$$

Where:

- A: Flow area $\left(\mathrm{m}^{2}\right)$

- C: Concentration $\left(\mathrm{kg} / \mathrm{m}^{3}\right)$

- D: Dispersion coefficient

- q: Lateral inflow $\left(\mathrm{m}^{2} / \mathrm{s}\right)$

- K: biodegradable coefficient, $\mathrm{K}$ is only used when the phenomenon related to biochemical reactions.

ECOlab is accompanied by the water quality template, which is divided into six levels. This study use "level $4+$ Photphorus + Coliform".

\subsection{Formula to Assess Capacity of Receiving Wastewater}

Assessing the capacity of receiving wastewater of Thuong river is conducted by the following steps: (i) Zoning river sections; (ii) Calculating the maximum pollution load of pollutants (Ltđ); (iii) Calculating background pollutant load (Ln); (iv) Calculating of pollution load of waste source (Lt); (v) Calculating the capacity to receive wastewater (Ltn); These formula based on the Circular 09/2009/TT-BTNMT, MONRE Vietnam [3].

$$
\begin{gathered}
L_{t \mathrm{~d}}=\left(Q_{s}+Q_{t}\right) \times C_{t c} \times 86.4 \\
L_{n}=Q_{s} \times C_{s} \times 86.4
\end{gathered}
$$




$$
\begin{gathered}
L_{t}=Q_{t} \times C_{t} \times 86.4 \\
L_{t n}=\left(L_{t đ}-L_{n}-L_{t}\right) \times F_{s}
\end{gathered}
$$

Where:

- $\mathrm{L}_{\mathrm{td}}(\mathrm{kg} /$ day) is the maximum pollution load of the water sources for contaminants under review;

- $\mathrm{L}_{\mathrm{n}}(\mathrm{kg} /$ day): pollution load which are available in the receiving water sources

- $\mathrm{L}_{\mathrm{t}}(\mathrm{kg} /$ day): the pollution load in the waste source;

- $\mathrm{L}_{\mathrm{tn}}(\mathrm{kg} /$ day): capacity of receiving the pollution load of water source.

- $\mathrm{Q}_{\mathrm{s}}\left(\mathrm{m}^{3} / \mathrm{s}\right)$ is the instantaneous minimum flow measured at water quality monitoring sites.

- $\mathrm{Q}_{\mathrm{t}}\left(\mathrm{m}^{3} / \mathrm{s}\right)$ is the maximum wastewater discharge of waste sources;

$-\mathrm{C}_{\mathrm{tc}}(\mathrm{mg} / \mathrm{l})$ is the concentration limit values of pollutants under consideration specified in water quality standards to ensure the use of water resources.

- $\mathrm{C}_{\mathrm{s}}(\mathrm{mg} / \mathrm{l})$ : the maximum concentration value of the of pollutants in the water sources before receiving wastewater;

- $\mathrm{C}_{\mathrm{t}}(\mathrm{mg} / \mathrm{l})$ : the maximum concentration values of pollutants in wastewater.

- 86.4 is dimensional conversion coefficient from $(\mathrm{m} 3 / \mathrm{s}) \mathrm{x}$ $(\mathrm{mg} / \mathrm{l})$ to $(\mathrm{kg} / \mathrm{day})$.

- $\mathrm{F}_{\mathrm{s}}$ : safety coefficient $(0,3<\mathrm{Fs}<0,7)$.

If $\mathrm{L}_{\mathrm{tn}}$ is greater than $(>) 0$, the water can still receive pollutants. If $\mathrm{L}_{\mathrm{tn}}$ is less than or equal $(\leq) 0$, it means that the water is no longer able to receive pollutants.

\section{Research Results}

\subsection{The Result of Hydrodynamic Simulation}

Calibrating HD module aims to finding the hydraulic parameters, by adjusting Manning roughness coefficient so that the measured and calculated water levels are matched. After adjusting parameters, the HD module with time step of $\Delta \mathrm{t}=5$ minutes, the Manning roughness coefficients ranged from $0,012-0,032$.

The river network diagram of study area is described in Figure 3. The results of calibration and verification of hydrodynamic module are shown in Figure 4 - 5.

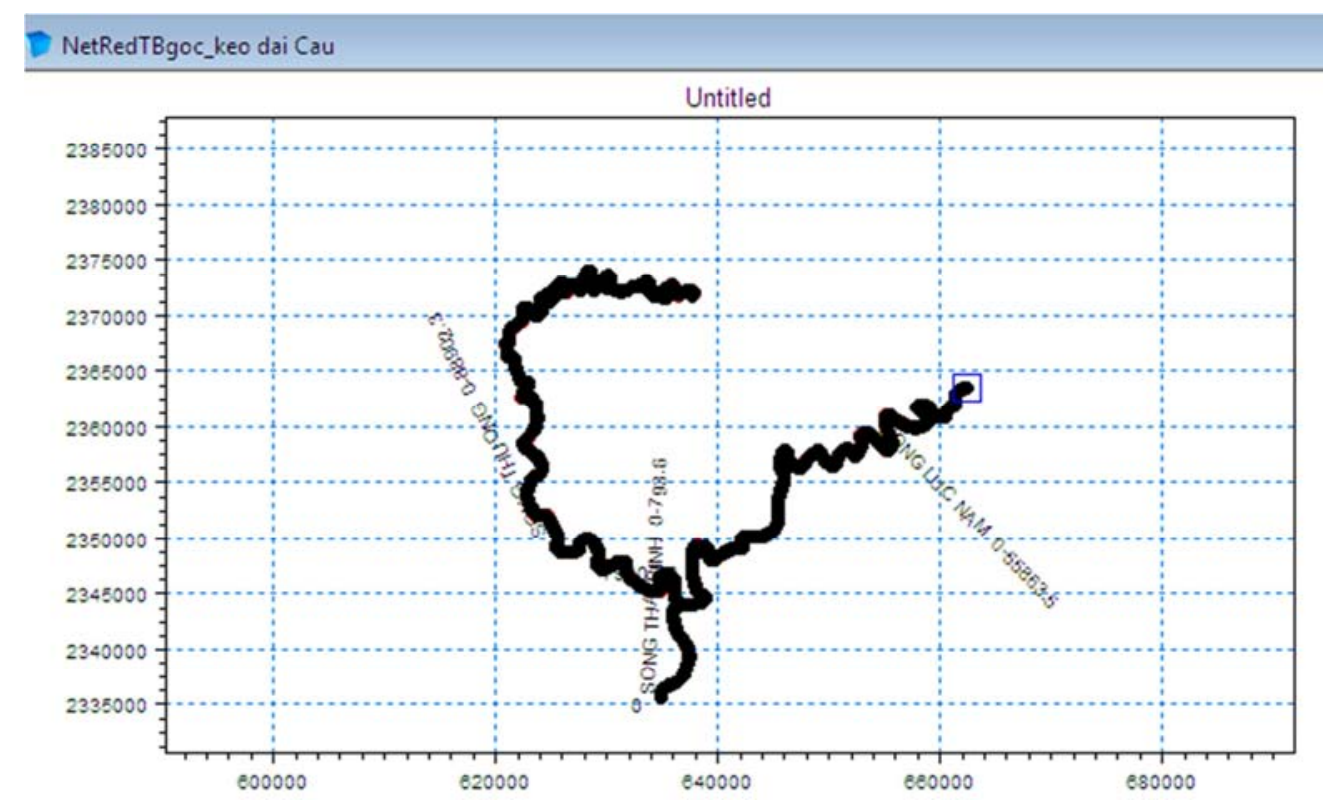

Figure 3. The river network diagram.

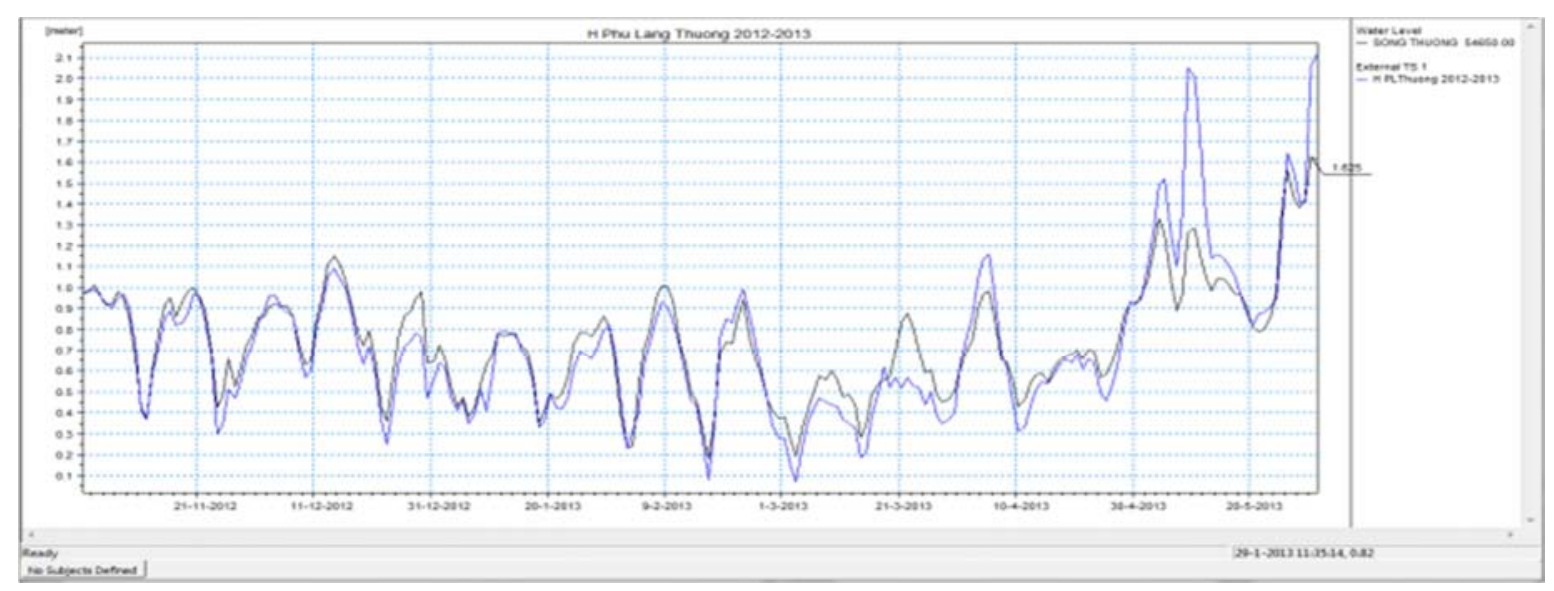

Figure 4. Calibration of water level at Phu Lang Thuong station. 


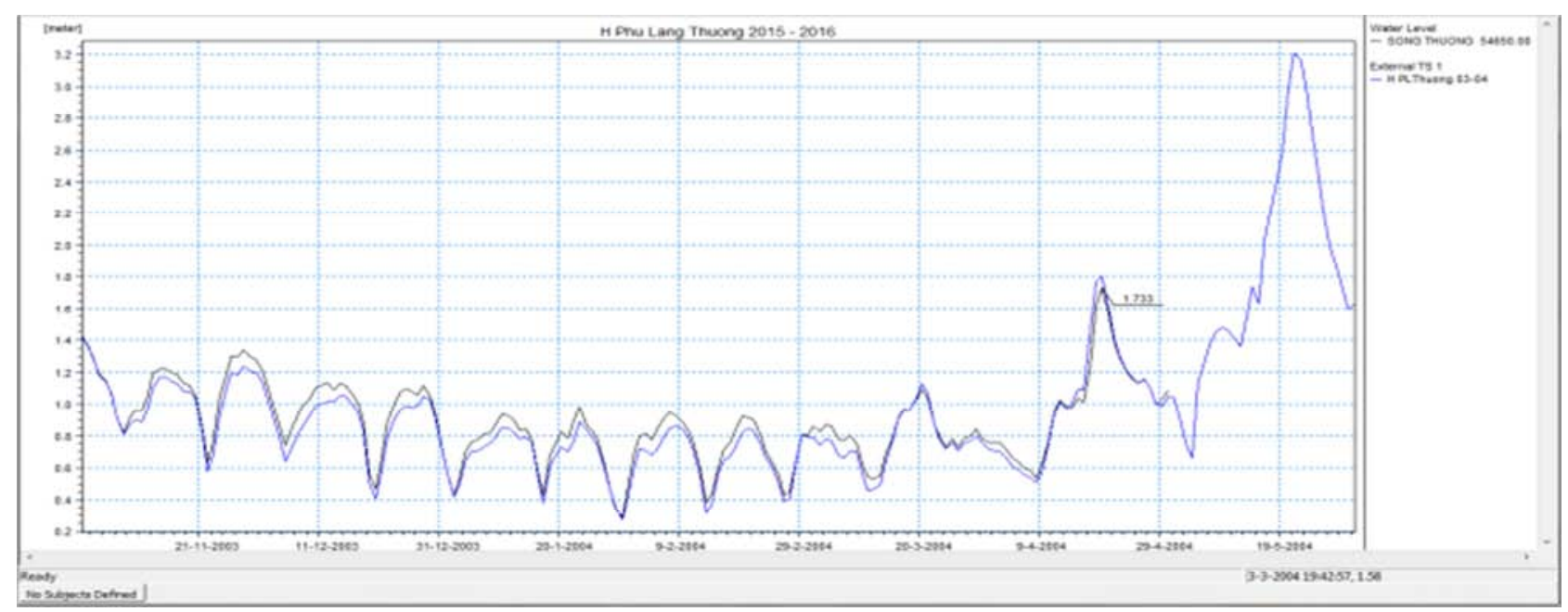

Figure 5. Verification of water level at Phu Lang Thuong station.

The accuracy of the model was assessed by Nash-Sutcliffe index. It must be mentioned that with higher amount of performance coefficient, the model results are more accurate [9]. The NASH coefficient at Phu Lang Thuong station is 98\% (Calibration) and 94\% (Verification). Thus, it is possible to use HD module as input data for AD and Ecolab module (water quality simulation).

\subsection{The Result of Water Quality Simulation}

Water quality data observed in March 2013 and in March 2016 are used for calibration and verification water quality module respectively.

1. The calibration results are presented in Figure $6-12$.

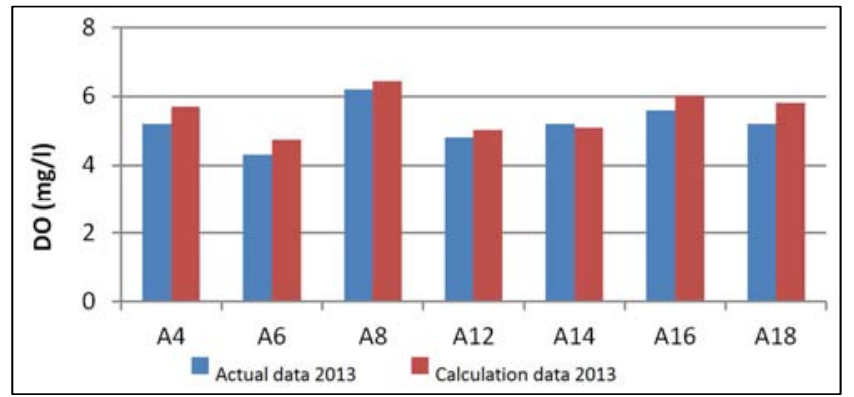

Figure 6. Calibration of DO concentration.

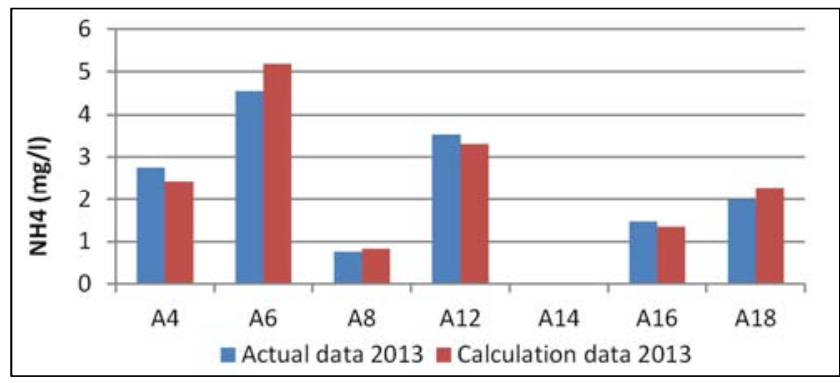

Figure 7. Calibration of $\mathrm{NH}_{4}^{+}$concentration.

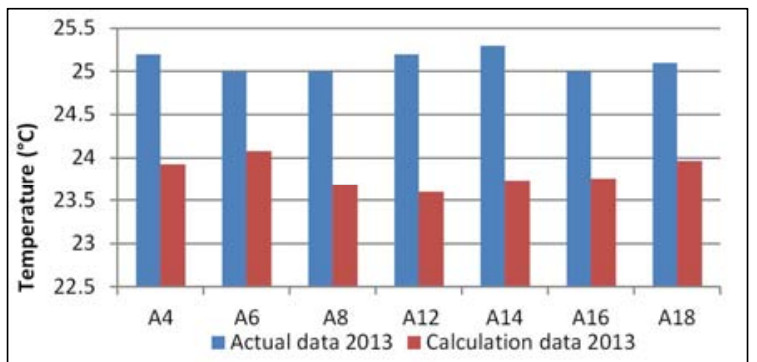

Figure 8. Calibration of Temperature concentration.

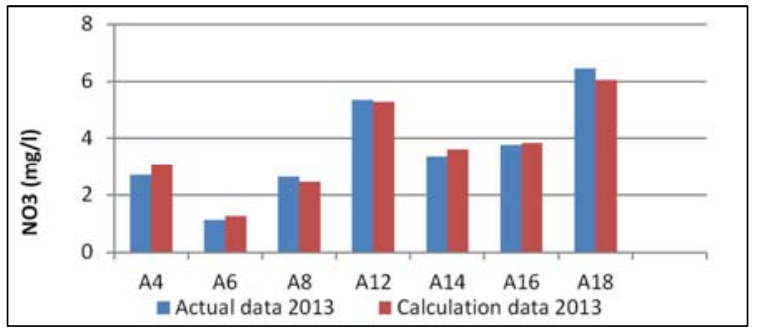

Figure 9. Calibration of $\mathrm{NO}_{3}^{-}$concentration.

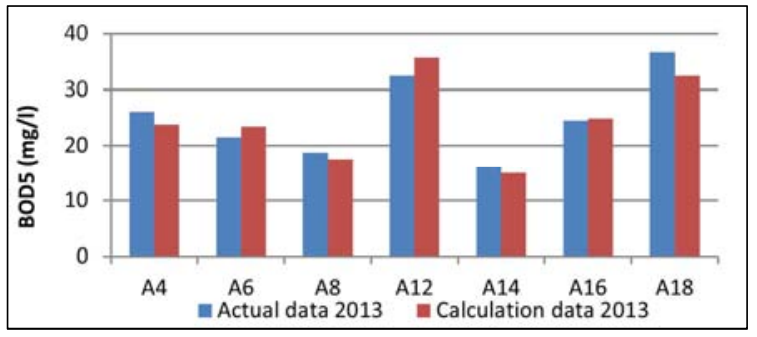

Figure 10. Calibration of $\mathrm{BOD}_{5}$ concentration.

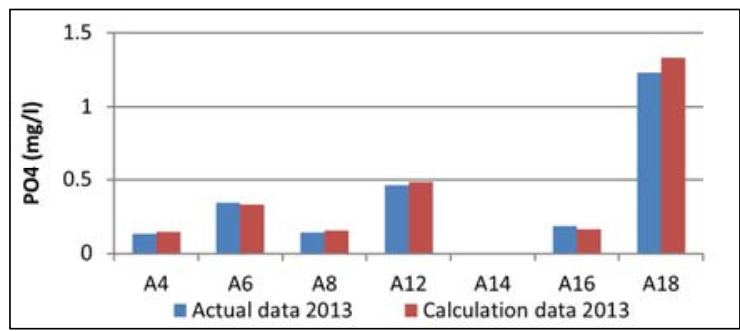

Figure 11. Calibration of $\mathrm{PO}_{4}{ }^{3-}$ concentration. 


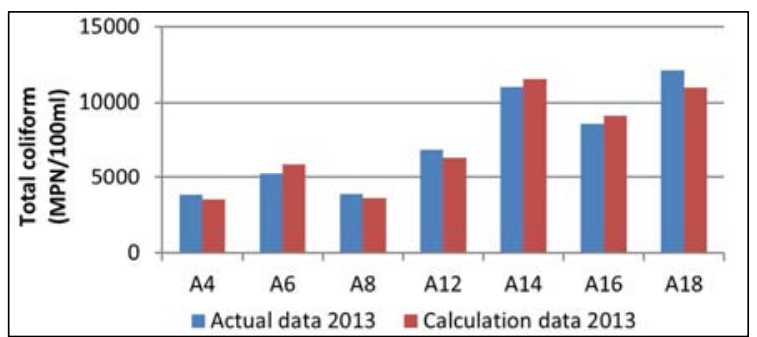

Figure 12. Calibration of Total Coliform concentration.

The calibration of water quality module aims to find the optimal model parameters for study area. The reliability of the parameters is shown by the calibration results as the deviation between measured data and simulated data, as follows: The deviation of temperature is from $0.08-0.22$ degrees; DO: $0,67 \mathrm{mg} / \mathrm{l}-0,24 \mathrm{mg} / \mathrm{l} ; \mathrm{NH}_{4}: 0,01 \mathrm{mg} / 1$ - 0,14mg/1, $\mathrm{NO}_{3}: 0,01 \mathrm{mg} / 1$ - 0,06mg/l, BOD ${ }_{5}: 0.1 \mathrm{mg} / \mathrm{l}$ - 0.2mg/l, $\mathrm{PO}_{4}: 0.005 \mathrm{mg} / \mathrm{l}$ 0.01mg/l, Coliform: $170 \mathrm{MNP} / 100 \mathrm{ml}-680 \mathrm{MNP} / 10 \mathrm{ml}$. All these deviation are under the allowable limit (10\%).

To assess the accuracy of parameters found in the calibration process, continue using these parameters for the verification step with surveyed data in 2016.

The verification results are presented in Figure 13 - 19.

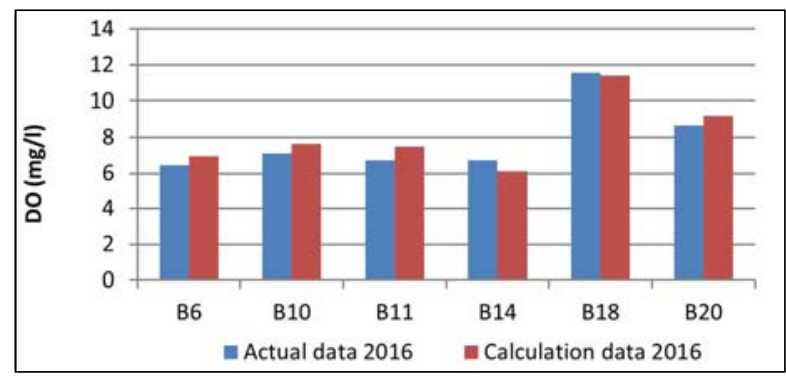

Figure 13. Verification of DO concentration.

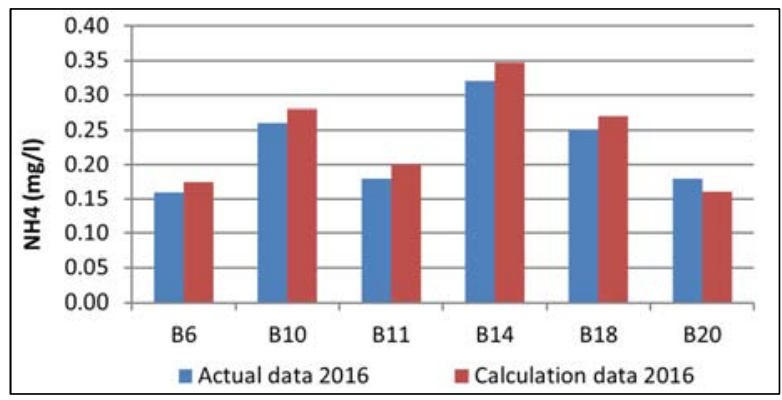

Figure 14. Verification of $\mathrm{NH}_{4}^{+}$concentration.

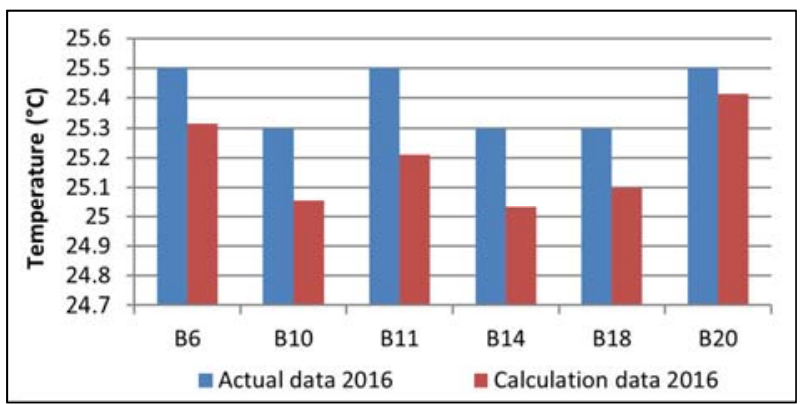

Figure 15. Verification of Temperature concentration

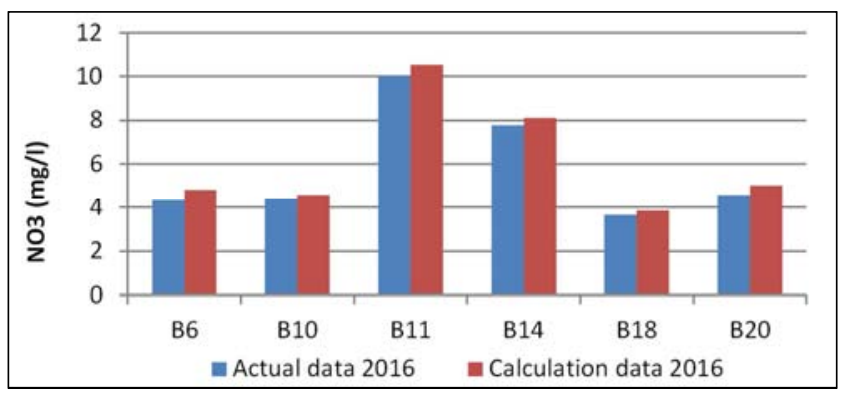

Figure 16. Verification of $\mathrm{NO}_{3}^{-}$concentration.

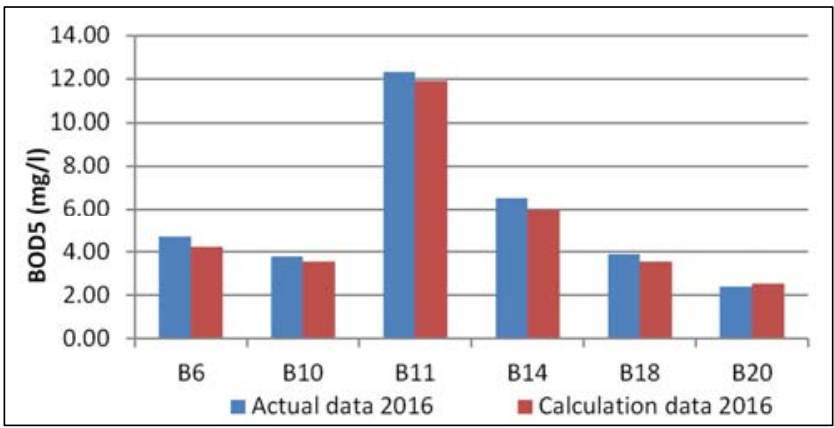

Figure 17. Verification of $\mathrm{BOD}_{5}$ concentration.

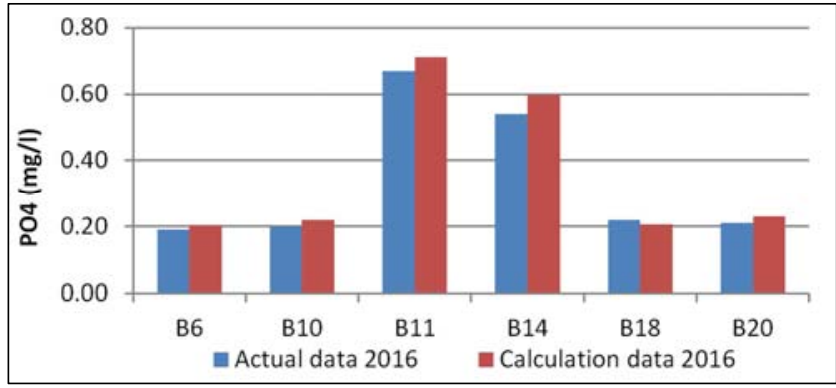

Figure 18. Verification of $\mathrm{PO}_{4}^{3-}$ concentration.

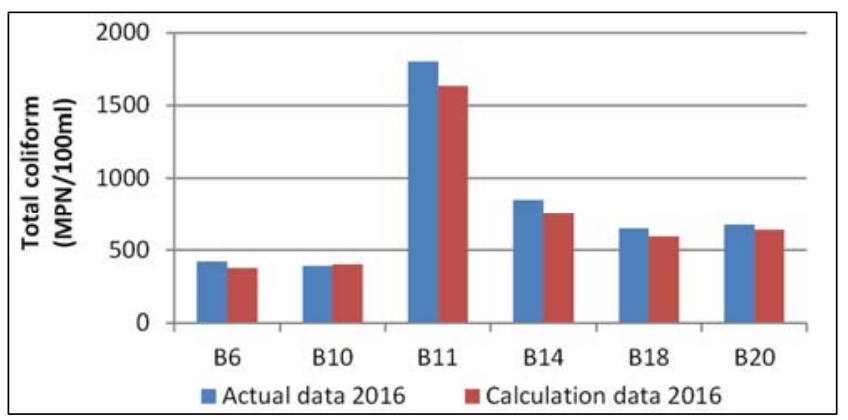

Figure 19. Verification of Total coliform concentration.

The results indicated that deviation range of temperature is 0.1 - 0.3 degrees Celsius; DO: $0.2 \mathrm{mg} / 1-0.8 \mathrm{mg} / \mathrm{l} ; \mathrm{NH}_{4}^{+}$: $0,01 \mathrm{mg} / \mathrm{l}-0,03 \mathrm{mg} / \mathrm{l} ; \mathrm{NO}_{3}{ }^{-}: 0,18 \mathrm{mg} / 1-0.45 \mathrm{mg} / 1 ; \mathrm{PO}_{4}{ }^{3-}$ : 0,01mg/1 - $0.06 \mathrm{mg} / \mathrm{l}$; $\mathrm{BOD}_{5}$ : $0.14 \mathrm{mg} / \mathrm{l}-0.52 \mathrm{mg} / \mathrm{l}$, Coliform: 11.7MNP/100ml - 165,2MNP/10ml.

Deviation between measured data and simulated data is under the allowable limit $(10 \%)$. Thus, can use the model to predict water quality in the future. 


\subsection{Prediction of Water Quality of Thuong River by MIKE 11 Model}

Based on the planning on economic - social development and water resources in 2020 and 2030 of Bac Giang [4, 11], predict the wastewater discharge to Thuong river in 2020 and 2030 as follows:

Table 2. Prediction of wastewater discharge to Thuong river in 2020 and 2030 .

\begin{tabular}{llll}
\hline \multirow{2}{*}{ Year } & \multicolumn{3}{l}{ Wastewater discharge $\left(\mathbf{m}^{3} /\right.$ day $)$} \\
\cline { 2 - 4 } & Domestic & Industry & Agriculture \\
\hline 2020 & $43.623,28$ & 963.904 & 41.507 \\
2030 & $48.260,94$ & 5.550 .411 & 77.488 \\
\hline
\end{tabular}

Using the hydraulic and water quality parameters found above and wastewater discharge forecast in 2020 and 2030 (Table 2), predict water quality of Thuong river under 3 scenarios:

- Scenario 1: The amount of waste water in the basin increased according to plan, but untreated.

- Scenario 2: The amount of waste water in the basin increased according to plan, but $30 \%$ was treated.

- Scenario 3: The amount of industrial waste water in the basin increased according to plan, but $70 \%$ was treated and achieve the industrial wastewater standard.

The simulated concentrations of pollutants are compared with the National technical regulation on surface water quality, 2015, A2 column for domestic purpose) [12]. The results of water quality prediction under 3 scenarios are shown below (Figure 20-31):

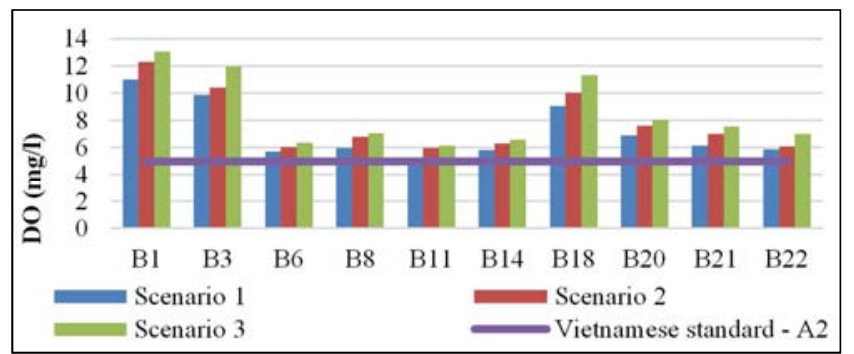

Figure 20. DO concentration in 2020.

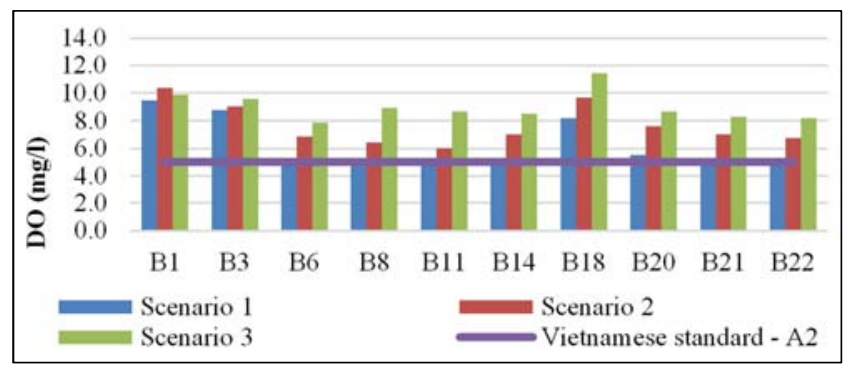

Figure 21. DO concentration in 2030.

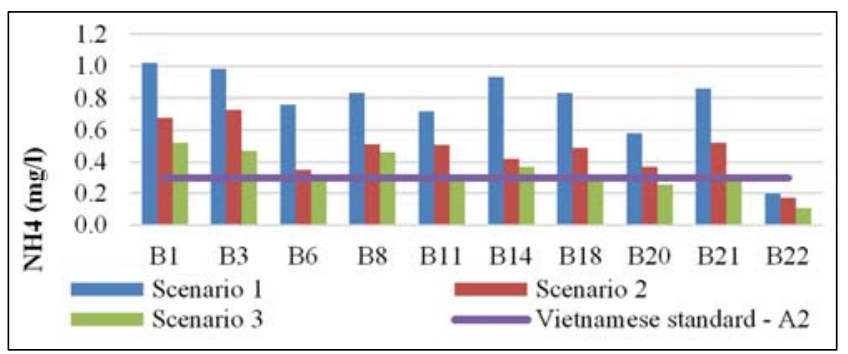

Figure 22. $\mathrm{NH}_{4}^{+}$concentration in 2020 .

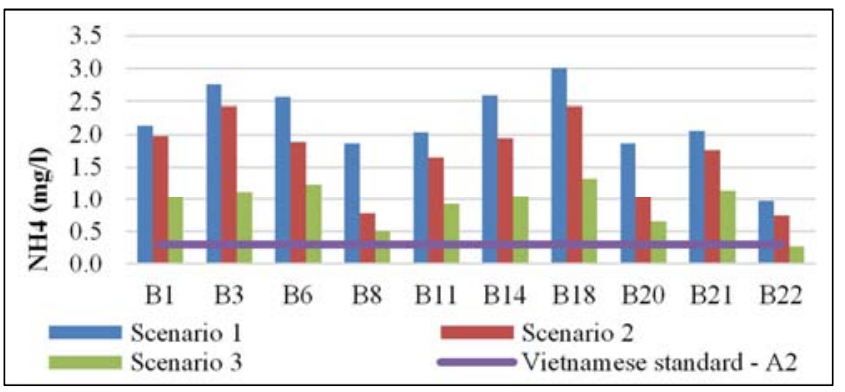

Figure 23. $\mathrm{NH}_{4}^{+}$concentration in 2030 .

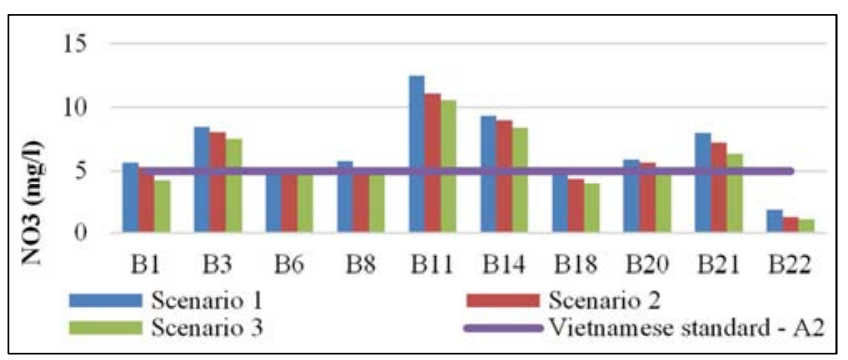

Figure 24. $\mathrm{NO}_{3}^{-}$concentration in 2020.

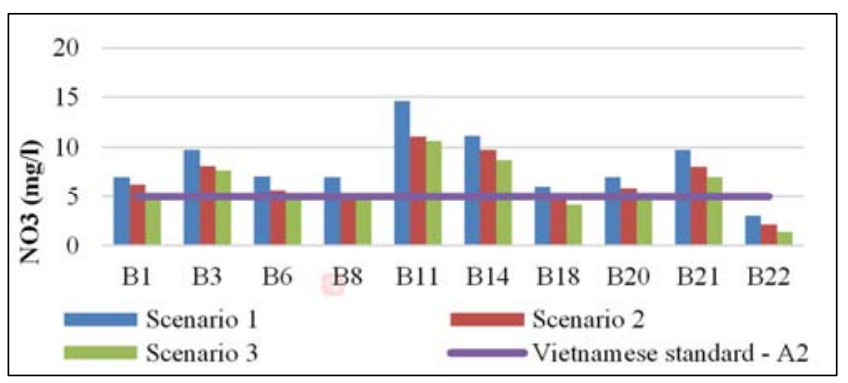

Figure 25. $\mathrm{NO}_{3}^{-}$concentration in 2030.

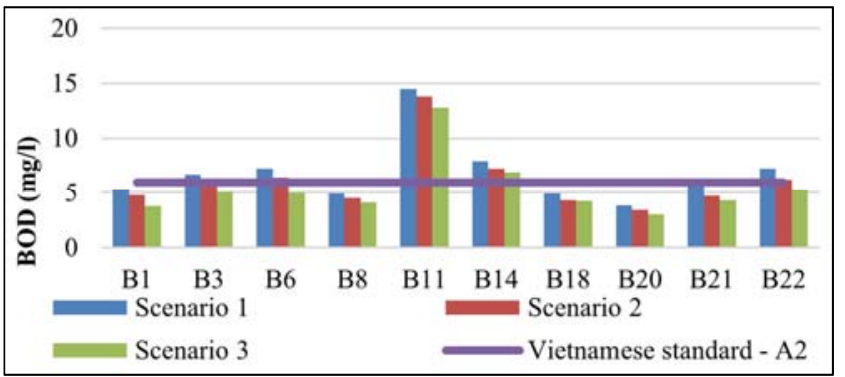

Figure 26. $\mathrm{BOD}_{5}$ concentration in 2020 


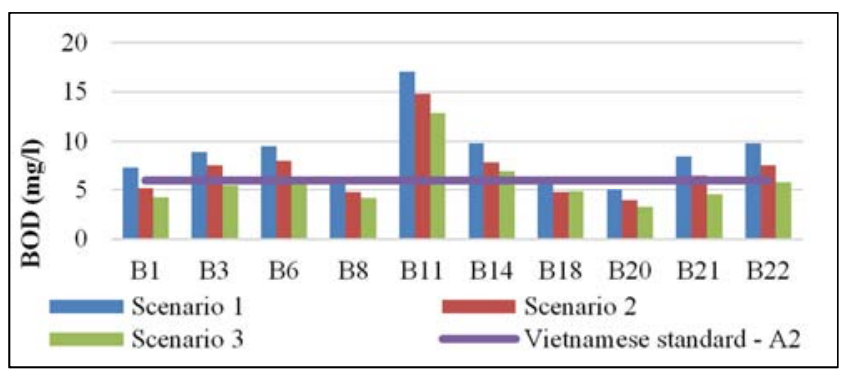

Figure 27. $B O D_{5}$ concentration in 2030.

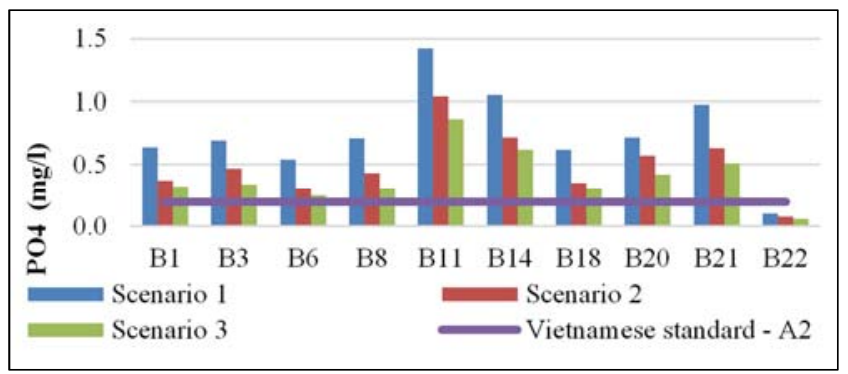

Figure 28. $\mathrm{PO}_{4}^{3-}$ concentration in 2020.

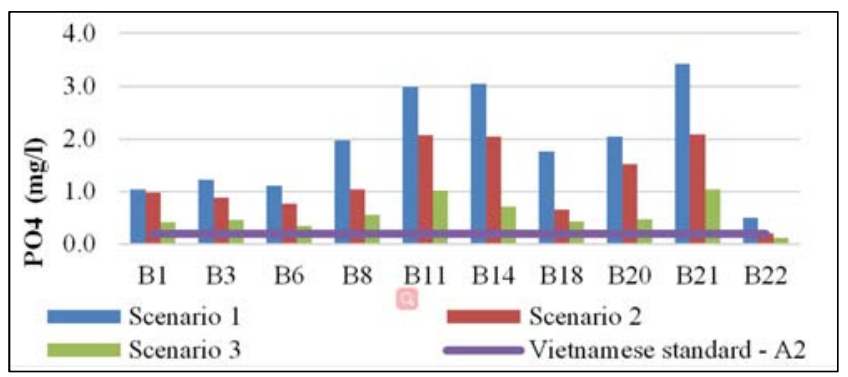

Figure 29. $\mathrm{PO}_{4}{ }^{3-}$ concentration in 2030.

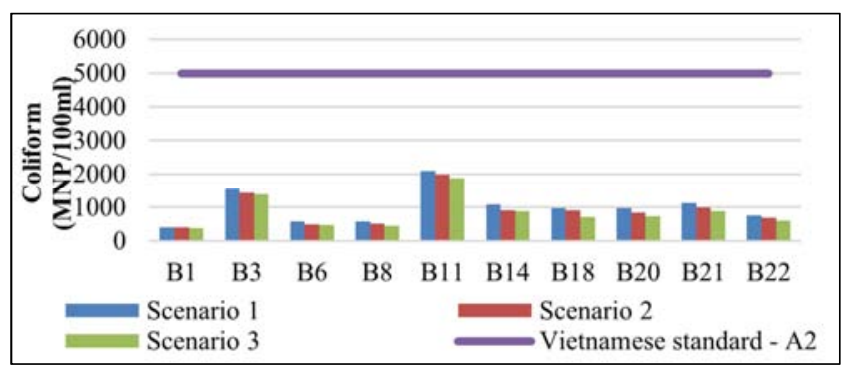

Figure 30. Coliform concentration in 2020.

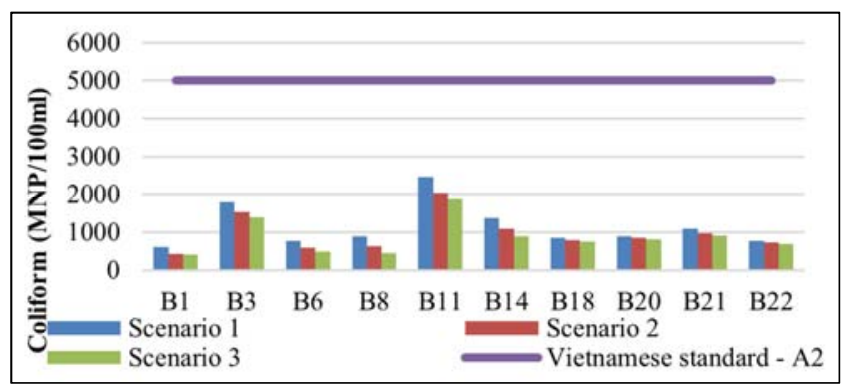

Figure 31. Coliform concentration in 2030.
Map of zoning Thuong river's sections

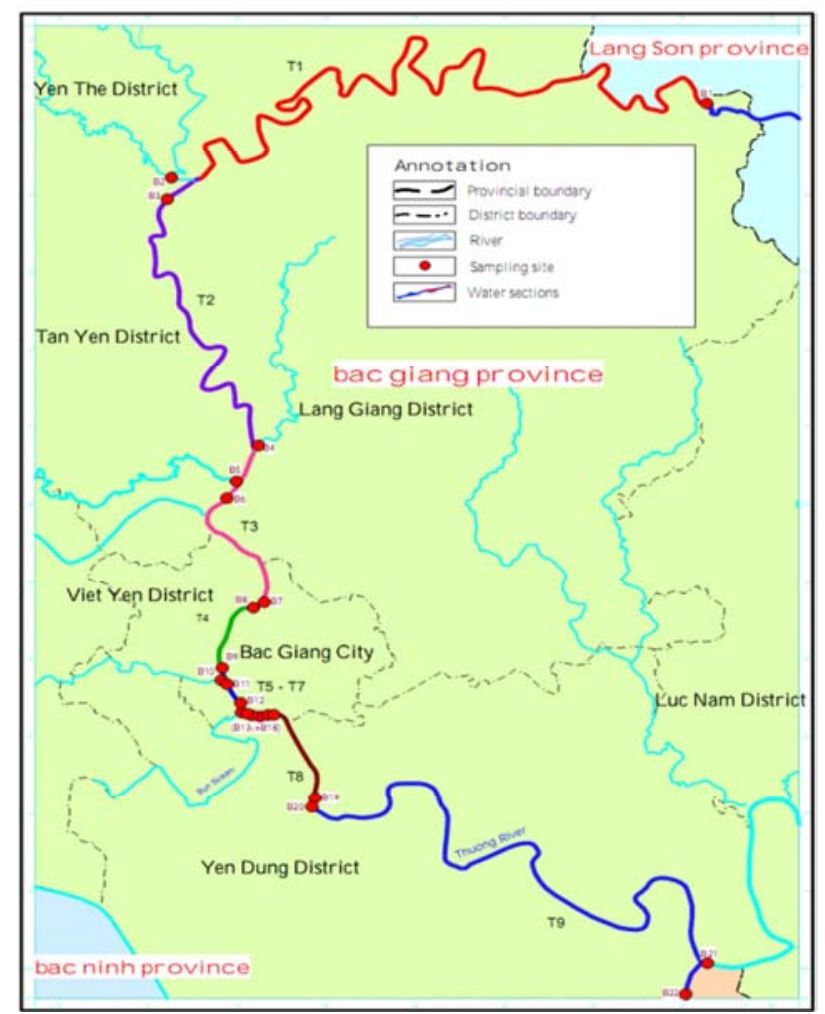

Figure 32. Map of zoning river sections.

The simulated results of water quality of Thuong river in 2020 and 2030 indicated that:

1. Scenario in 2020:

- DO: DO concentration under 3 scenarios are within the allowed limit.

- $\mathrm{NH}_{4}^{+}: \mathrm{NH}_{4}^{+}$concentrations are mostly beyond the standard, from 1,9 to 3,27 times (scenario 1); 1,2 to 2,4 times (scenario 2) and less than 1.7 times (scenario 3). In particular, the water quality at Pha Lai station is within the standard in both 3 scenarios.

- $\mathrm{NO}_{3}{ }^{-}$: In scenario 1 and 2, the concentration of $\mathrm{NO} 3$ mostly exceeds the standard. At some points B1, B6, B8, B18 and $\mathrm{B} 20$, the concentrations exceed negligibly. The $\mathrm{NO}_{3}{ }^{-}$ concentration of remaining points exceed less than 2.5 times.

- $\mathrm{BOD}_{5}: \mathrm{BOD}_{5}$ concentration is within the standard in scenario 3 , and does not significantly exceeded in scenarios 1 and 2, except the concentrations at point B11 exceed standard 2 times in 3 scenarios.

- $\mathrm{PO}_{4}{ }^{3-}: \mathrm{PO}_{4}{ }^{3-}$ concentrations of scenario 1 are higher 4 times in comparision with standard while 0,5 - 3 times in scenario 2 and 3 . In particular case of point B22, PO4 is within the permitted standard.

- Coliform: no sign of coliform contamination in 3 scenarios.

2. Scenario in 2030:

- DO: DO concentrations are within the allowed limit for 3 simulated scenarios.

- $\mathrm{NH}_{4}^{+}$: The values of $\mathrm{NH}_{4}^{+}$exceed 12 times compared with standard in scenario 1 and $0,5-8$ times in 2 remaining 
scenarios.

$-\mathrm{NO}_{3}{ }^{-}: \mathrm{NO}_{3}{ }^{-}$concentrations are higher than the standard in 3 scenarios except the point of $\mathrm{B} 18$ and $\mathrm{B} 22$.

- $\mathrm{BOD}_{5}$ : $\mathrm{BOD}_{5}$ exceeded 2.8 times in scenario 1 and 2, but within the standard in scenario 3.

- $\mathrm{PO}_{4}{ }^{3-}$ : The value of $\mathrm{PO}_{4}{ }^{3-}$ exceeds standard in 3 scenarios, from 2,5-15,2 times in scenario 1; 3,8 - 10,4 times in scenario 2 and 1,1 - 3,55 times in scenario 3 .
- Coliform: no sign of coliform contamination in 3 scenarios.

\subsection{Assessing the Capacity of Receiving Wastewater of Thuong River}

Zoning Thuong river into 9 sections to assess the capacity of receiving wastewater of each section (Table 3 ) through 4 pollution indicators: $\mathrm{NH}_{4}{ }^{+}, \mathrm{NO}_{3}{ }^{-}, \mathrm{BOD}_{5}{ }^{\prime} \mathrm{PO}_{4}{ }^{3+}$.

Table 3. Zoning river sections.

\begin{tabular}{llll}
\hline \multicolumn{2}{l}{ Section } & Distance $\mathbf{( k m )}$ & Description \\
\hline T1 & B1 - B2 & 32.5 & No wastewater discharge \\
T2 & Behind B2 - B4 & 12.58 & Wastwater from Duong Duc sewage \\
T3 & Behind B4 - B7 & 6.05 & Wastwater from Ha Bac fertilizer plant \\
T4 & Behind B7 - B9 & 3.74 & Wastwater from Chi Ly pumping station \\
T5 & Behind B9 - B12 & 0.58 & Wastwater from Nha Dau pumping station \\
T6 & Behind B12 - B15 & 0.58 & Wastwater from Dong Cua pumping station \\
T7 & Behind B15 - B18 & 0.58 & Wastwater from Chau Xuyen 2, Chau Xuyen 1 pumping station \\
T8 & Behind B18 - B20 & 3.35 & Wastwater from Wastewater Treatment Plant \\
T9 & Behind B20 - B22 & 20 & No wastewater discharge \\
\hline
\end{tabular}

Application the formula in the Methodology section, the results of calculating capacity of receiving wastewater of Thuong river as follow:

Table 4. The capacity of receiving wastewater of Thuong river in 2020 (kg/day).

\begin{tabular}{|c|c|c|c|c|c|c|c|c|c|c|c|c|}
\hline \multirow{2}{*}{$\begin{array}{l}\text { River } \\
\text { section }\end{array}$} & \multicolumn{4}{|c|}{ Scenario 1} & \multicolumn{4}{|c|}{ Scenario 2} & \multicolumn{4}{|c|}{ Scenario 3} \\
\hline & $\mathrm{NH}_{4}^{+}$ & $\mathrm{NO}_{3}^{-}$ & BOD $_{5}$ & $\mathrm{PO}_{4}{ }^{3-}$ & $\mathrm{NH}_{4}{ }^{+}$ & $\mathrm{NO}_{3}^{-}$ & BOD $_{5}$ & $\mathrm{PO}_{4}{ }^{3-}$ & $\mathrm{NH}_{4}^{+}$ & $\mathrm{NO}_{3}^{-}$ & BOD $_{5}$ & $\mathrm{PO}_{4}{ }^{3-}$ \\
\hline 1 & -68.91 & -425.93 & -236.63 & -103.43 & -58.03 & -3.01 & 214.08 & -75.77 & 27.06 & 303.08 & 423.35 & -19.84 \\
\hline 2 & -49.55 & -4469.15 & -2311.91 & -452.92 & -862.43 & -2747.57 & -898.77 & -238.28 & -413.76 & -354.28 & -159.54 & -0.31 \\
\hline 3 & -255.55 & -2635.73 & -2640.74 & -507.64 & -1969.69 & -1736.39 & -1046.85 & -325.57 & -1054.56 & 20.00 & -198.25 & -131.22 \\
\hline 4 & -232.68 & 762.52 & 1075.17 & -246.83 & -212.29 & 644.71 & 1176.15 & -233.96 & -188.44 & 704.61 & 1215.65 & -235.49 \\
\hline 5 & -659.71 & -2168.23 & -1463.64 & -302.62 & -452.39 & -1125.02 & 795.87 & -125.61 & 36.70 & 789.57 & 1327.34 & -21.86 \\
\hline 7 & -1303.10 & -197.75 & -215.05 & -215.33 & -1002.40 & 319.17 & 380.00 & -137.93 & -326.68 & 530.91 & 811.10 & -90.16 \\
\hline 8 & -238.36 & -248.01 & -374.99 & -64.80 & -150.29 & -88.65 & -139.71 & -31.04 & -61.95 & 46.67 & -1.79 & -6.55 \\
\hline 9 & -521.46 & -479.11 & -595.96 & -207.98 & -357.96 & -63.20 & -12.01 & -130.90 & -85.72 & 92.90 & 140.94 & -60.42 \\
\hline
\end{tabular}

Table 5. The capacity of receiving wastewater of Thuong river in 2030 (kg/day).

\begin{tabular}{|c|c|c|c|c|c|c|c|c|c|c|c|c|}
\hline \multirow{2}{*}{ River stretch } & \multicolumn{4}{|c|}{ Scenario 1} & \multicolumn{4}{|c|}{ Scenario 2} & \multicolumn{4}{|c|}{ Scenario 3} \\
\hline & $\mathrm{NH}_{4}^{+}$ & $\mathrm{NO}_{3}^{-}$ & BOD $_{5}$ & $\mathrm{PO}_{4}{ }^{3-}$ & $\mathrm{NH}_{4}{ }^{+}$ & $\mathrm{NO}_{3}^{-}$ & BOD $_{5}$ & $\mathrm{PO}_{4}{ }^{3-}$ & $\mathrm{NH}_{4}{ }^{+}$ & $\mathrm{NO}_{3}^{-}$ & BOD $_{5}$ & $\mathrm{PO}_{4}{ }^{3-}$ \\
\hline $\mathrm{T} 1$ & -165.73 & -847.66 & -952.23 & -139.51 & -121.17 & -397.73 & -428.16 & -99.82 & -23.45 & -31.27 & -173.19 & 0.00 \\
\hline $\mathrm{T} 2$ & -1614.78 & -5890.19 & -3627.24 & -698.66 & -1171.65 & -3755.41 & -1593.19 & -380.51 & -577.96 & -621.88 & -337.58 & 362.86 \\
\hline $\mathrm{T} 3$ & -3191.66 & -3266.82 & -3502.66 & -686.59 & -2439.58 & -2207.77 & -1464.84 & -443.88 & -1314.84 & -117.84 & -265.24 & 680.40 \\
\hline $\mathrm{T} 4$ & -317.92 & 52.51 & 104.09 & -266.95 & -287.68 & 106.61 & 237.86 & -249.43 & -256.88 & 188.85 & 299.51 & 24.10 \\
\hline T5 & -983.97 & -3374.82 & -3439.18 & -413.48 & -658.99 & -2220.77 & -946.03 & -196.12 & -107.61 & -108.50 & -173.88 & 79.10 \\
\hline $\mathrm{T} 7$ & -1705.26 & -944.53 & -1468.65 & -311.39 & -1297.83 & -307.79 & -661.74 & -202.92 & -479.27 & 28.45 & -30.23 & 443.88 \\
\hline $\mathrm{T} 8$ & -285.89 & -348.44 & -527.97 & -88.88 & -191.67 & -157.47 & -221.42 & -44.43 & -83.43 & 25.43 & -13.78 & 28.52 \\
\hline T9 & -7637.96 & -6803.02 & -7246.99 & -1262.93 & -5162.79 & -2906.51 & -1751.33 & -775.28 & -2229.14 & -86.39 & 1583.24 & 1785.12 \\
\hline
\end{tabular}

Explain the calculation results of capacity of receiving waste water:

- The positive values: the river segment still have capacity of receiving wastewater, in which the maximum pollutant load which the segment can receive is the values are highlighted in yellow.

- The negative values: the river segment is no longer capacity of receiving pollutants. The negative value shows pollutant load exceeds the capacity to receive.

\section{In 2020:}

- In scenario 1, almost sections are not able to get any pollutant load of $\mathrm{NH}_{4}^{+}, \mathrm{NO}_{3}^{-}, \mathrm{BOD}_{5}, \mathrm{PO}_{4}^{3-}$, only section $\mathrm{T} 4$ can receive wastewater with pollutant load of $\mathrm{NO}_{3}{ }^{-}$and $\mathrm{BOD}_{5}$ is $52.5 \mathrm{~kg} /$ day and $104.09 \mathrm{~kg} /$ day.

- In scenario 2, the capacity is higher than the scenario 1 , section $\mathrm{T} 4$ and $\mathrm{T} 7$ can receive wastewater with load of $\mathrm{NO}_{3}{ }^{-}$ is $644.7 \mathrm{~kg} / \mathrm{day}$ and $319.16 \mathrm{~kg} /$ day; while the remaining river sections can receive wastewater with load of $\mathrm{BOD}_{5}$ such as 
section 1 (214.08 kg/day), section 4 (1176.15kg/day), section $5(795.87 \mathrm{~kg} /$ day $)$, section $6(71.48 \mathrm{~kg} /$ day $)$ and section 7 (380 kg/day).

- In scenario 3, due to $70 \%$ waste water is treated, so the capacity is higher than 2 above scenarios:

+ For $\mathrm{NH}_{4}^{+}$: Section T1 and T5 are able to receive the load of $27.06 \mathrm{~kg} /$ day and $36.7 \mathrm{~kg} /$ day.

+ For $\mathrm{NO}_{3}^{-:}$The section T1, T3, T4, T5, T6, T7, T8 and T9 can receive the pollutant load of $303.077 \mathrm{~kg} / \mathrm{day} ; 20 \mathrm{~kg} /$ day; $704.6 \mathrm{~kg} /$ day; $789.6 \mathrm{~kg} /$ day; $112.49 \mathrm{~kg} /$ day; $530.9 \mathrm{~kg} /$ day; $46.67 \mathrm{~kg} /$ day; $92.89 \mathrm{~kg} /$ day respectively.

+ For $\mathrm{BOD}_{5}$ : The section T1, T4, T5, T6, T7 and T9 can receive the pollutant load of $423.34 \mathrm{~kg} /$ day; $1215.6 \mathrm{~kg} /$ day; $1327.341 \mathrm{~kg} /$ day; $199.5252 \mathrm{~kg} /$ day; $811.1026 \mathrm{~kg} /$ day and $140.94 \mathrm{~kg} /$ day.

+ For $\mathrm{PO}_{4}{ }^{3-}$ : Cannot receive wastewater on all river sections.

2. In 2030:

Wastewater flow data in 2030 increases compared to 2020, thus the capacity of receiving waste water has signs of decline.

- Scenario 1: Almost sections are not able to get any pollutant load of $\mathrm{NH}_{4}{ }^{+}, \mathrm{NO}_{3}{ }^{-}, \mathrm{BOD}_{5}, \mathrm{PO}_{4}{ }^{3-}$, section $\mathrm{T} 4$ can receive wastewater with load of NO3- and $\mathrm{BOD}_{5}$ is 52.51 $\mathrm{kg}$ /day and $104.09 \mathrm{~kg} /$ day.

- Scenario 2: Section T4 can receive the $\mathrm{NO}_{3}{ }^{-}$and $\mathrm{BOD}_{5}$ with load of $106.6 \mathrm{~kg} / \mathrm{day}$ and $237.86 \mathrm{~kg} / \mathrm{day}$.

- Scenario 3, 70\% wastewater is treated so the capacity is higher than 2 above scenarios:

+ For $\mathrm{NO}_{3}{ }^{-}$: The section $\mathrm{T} 4$ and $\mathrm{T} 8$ can receive the pollutant load of $188.85 \mathrm{~kg} /$ day and $28.45 \mathrm{~kg} /$ day respectively

+ For $\mathrm{BOD}_{5}$ : Section $\mathrm{T} 4$ can receive wastewater with load of $299.5 \mathrm{~kg} /$ day.

+ For $\mathrm{PO}_{4}{ }^{3-}$ : Section T2-T7 can receive the wastewater with load of $362.86 \mathrm{~kg} /$ day; $680.4 \mathrm{~kg} /$ day; $24.095 \mathrm{~kg}$ /day; $79.10 \mathrm{~kg} /$ day; $116.60 \mathrm{~kg} /$ day and $443.88 \mathrm{~kg} /$ day.

+ For $\mathrm{NH}_{4}{ }^{+}$: No longer capacity of receiving waste water in all river sections.

\section{Policy Proposals}

Facing with the current situation of river water pollution, it is necessary to propose appropriate policies to control wastewater discharge, reduce pollution and protect river water.

Some policies are suggested as follow:

1) Improving the State management effectiveness and efficiency to the wastewater discharge activities into water sources."

- Strengthening capacity for the state management staff.

+ Recruitment: people who have expertise, good qualifications, high responsibility good ethics and experience should be mobilized.

+ Capacity building: regular training and retraining for the staff should be implemented to enhance their capability to ensure effective implementation of the assigned functions. The appropriate training schedule should be developed;
Evaluation to the training efficiency is based on positive changes of their work.

+ It is required to build a good staffs that have good nature and knowledge regarding the legal issues to solve specific actual situations for controlling activities of discharging waste water into water sources.

+ Regular training on implementation of the Environmental Protection Law and other legal documents related to the Law implementation for local authorities and enterprises; promoting the environmental communication under various forms step by step to raise awareness of the community levels about environmental protection.

- Completing organizational structure for environmental protection from the local to National levels.

Specialized inspection functions for the Departments of Environmental Protection should be amended. Financial mechanism for, the environmental management at district and commune levels should be revised to meet the management requirements.

- Developing tools to support the management of waste water discharge into water sources.

Enacting a new Circular to guide assessment of the assimilative capacity of river by mathematical models instead of Circular 2009 (calculated by using outdated formulate).

- Tightening the inspection and management of wastewater discharge activities; Licensing discharge permits for localities at all levels from commune, district, city, province.

- Promoting the participation of the communities in the contaminated region to monitor and timely identify the facilities causing water pollution

- Implement strong sanctions.

2) All Strengthening investigation and monitoring wastewater discharge activities. facilities are required to install monitoring systems to supervise load and quality of wastewater.

The Government should direct the Ministries, agencies and the media across the country to implement awareness improvement program for the government staff and communities.

The Ministry of Training \& Education should integrate the knowledge of environmental protection into the training and educational curricula.

3) Raising the awareness of people and community involvement

The Government should enact policies to raise awareness for people to help them understand knowledge on the environment and environmental protection, policies to promote community participation in environmental protection, to have serious sanctions to any violations. It is required to develop a reasonable schedule and financial investments as well as to increase the efficiency of communication.

\section{Role of stakeholders}

The Ministry of Natural Resources and Environment should implement: (i) Capacity building program for staff of the MoNRE; (ii) Organization of training programs for officials at provincial, district and commune on the 
enforcement of legal documents as well as technical knowledge; (iii) Provision of technical tools to support decision making on environment management and protection; (iv) Inspection of the law enforcement to wastewater discharge facilities.

\section{Conclusions}

Thuong River plays an important role in water supply and waste water receiving for Bac Giang province. Currently, due to the urbanization, investment and improper operation of treatment works on environment, the increase in the pollution load of discharge into the river, the pollution load has exceeded the receiving capacity of the river.

The calculated results of the study show that the river pollution situation is increasingly serious and has no signs of stop, even when the wastewater is treated $30 \%$ and $70 \%$ before discharge into the river and the pollution is exceeded the permissible standards of Vietnam.

Therefore, we proposed some policies in order to control discharge wastewater, reduce pollution and protect river water including: (i) Improving the State management effectiveness and efficiency to the wastewater discharge activities into water sources; (ii) Strengthening investigation and monitoring wastewater discharge activities; (iii) Raising the awareness of people and community involvement.

\section{References}

[1] National Assembly of Vietnam. Law on Water Resources No. 17/2012/QH13, 2012. Available at: Law on Environmental Protection.
[2] Government of Vietnam. Decree No. 201/2013/ND-CP. "Regulate in Detail the implementation of some articles of the Law on Water Resources", 2013.

[3] MonRE. Circular 02/2009/TT/BTNMT. "Regulate principles of assessing the capacity of receiving waste water of rivers and streams".

[4] Department of Natural Resources and Environment of Bac Giang province. "Water resources planning in Bac Giang province in 2013". Bac Giang, Vietnam, 2013.

[5] Bac Giang Statistical Office. "Bac Giang Statistical Yearbook”. Bac Giang, Vietnam: Statistical publisher, 2015.

[6] MoNRE. "Vietnam Environmental status Report". Hanoi, Vietnam, 2012.

[7] Scott A. Socolofsky, Gerhard H. Jirka. "Mass Transfer and Diffusion." Institute for Hydromechanic, 2002.

[8] DHI. "Mike 11 - a modelling System for Rivers and Channels". Denmark, 2003.

[9] B. Razdara., K. Mohammadib., J. M. V. Samanic., B. Piroozd. "Determining the best water quality model for the rivers in north of Iran (Case study: Pasikhan River)", 2011.

[10] Thai. H. Tran. "Application of MIKE 11 model to forecast water quality of Cau river basin", Hanoi, Vietnam, 2003.

[11] Government of Vietnam. Decision No. 269/QĐ-TTg. "Approve the master plan for socio-economic development of Bac Giang province up to 2020 with a vision to 2030", 2015.

[12] MoNRE. "Vietnam National technical regulation on surface water quality, QCVN 08-MT: 2015/BTNMT”, 2015. 